\title{
PALEOGEOGRAPHIC SIGNIFICANCE OF MIDDLE PLEISTOCENE GLACIOMARINE DEPOSITS ON BALDWIN PENINSULA, NORTHWEST \\ ALASKA
}

\author{
by \\ Matt M. Huston, Julie Brigham-Grette \\ (Department of Geology and Geography, University of Massachusetts, Amherst, MA 01003, U.S.A.) \\ and \\ David M. Hopkins \\ (Department of Geology and Geophysics, University of Alaska, Fairbanks, AK 99701, U.S.A.)
}

\section{ABSTRACT}

Baldwin Peninsula, northwest Alaska, is a middle Pleistocene push-moraine complex composed of marine, fluvial, and glaciogenic sediments. The peninsula was formed by three ice lobes emanating from the De Long and Baird mountains and the Selawik Lowlands in the southwest Brooks Range during the Anaktuvuk River glaciation. This glaciation was nearly an order of magnitude more areally extensive than late Pleistocene glaciations in the same region and occurred c. 500 to $600 \mathrm{ka}$ B.P. based on paleomagnetism, and amino-stratigraphic and morphostratigraphic correlations with other numerically-dated northwest Alaskan deposits.

Extensive deposits of massive and laminated clayey silt with striated, faceted stones indicate that local sea level was high as glacial ice reached its maximum extent. Glacio-isostasy does not seem to have been important in maintaining a high relative sea level; therefore we infer that eustatic sea level remained high during ice advance. For this to occur, high latitude glaciation must have preceded the build-up of ice in lower latitudes. The source of moisture for such massive glaciation may have come from submerged Bering and Chukchi shelves, enhanced flow of North Pacific/southern Bering Sea winter storms, reduced intensity of the winter Arctic High, or a combination thereof.

\section{INTRODUCTION}

Tens of kilometers of glacially deformed middle Pleistocene marine, fluvial, and glaciogenic sediments are exposed on the southwest coast of Baldwin Peninsula $\left(66^{\circ} 40^{\prime} \mathrm{N}, 162^{\circ} 15^{\prime} \mathrm{W}\right)$, Kotzebue Sound, Alaska, U.S.A. (Fig. 1). The glacial origin of the peninsula was first noted by Hershey (1909), who thought it was Wisconsinan in age. The glacial drift was later assigned to the Illinoian glaciation by McCulloch and others (1965) and Coulter and others (1965), and the marine units were used to define Hopkins' (1967) pre-Illinoian Kotzebuan Transgression. More recent work by Hamilton (1986) and Kaufman and Hopkins (1986) ascribed the glacial deposits to pre-Illinoian time. Hamilton (1986) correlated the Baldwin deposits to the early or middle Pleistocene Anaktuvuk River glaciation. The entire sedimentary package at Baldwin Peninsula was glaciotectonically deformed by glaciers of the Anaktuvuk River glaciation.

The bulk of Baldwin Peninsula consists of glacial sediments and glaciotectonized marine deposits formed by three coalescing ice lobes which flowed generally southwest out of the Noatak, Kobuk, and Selawik river valleys in the southwestern Brooks Range (Fig. 1). The deposits of the glaciation that formed this moraine complex are nearly an

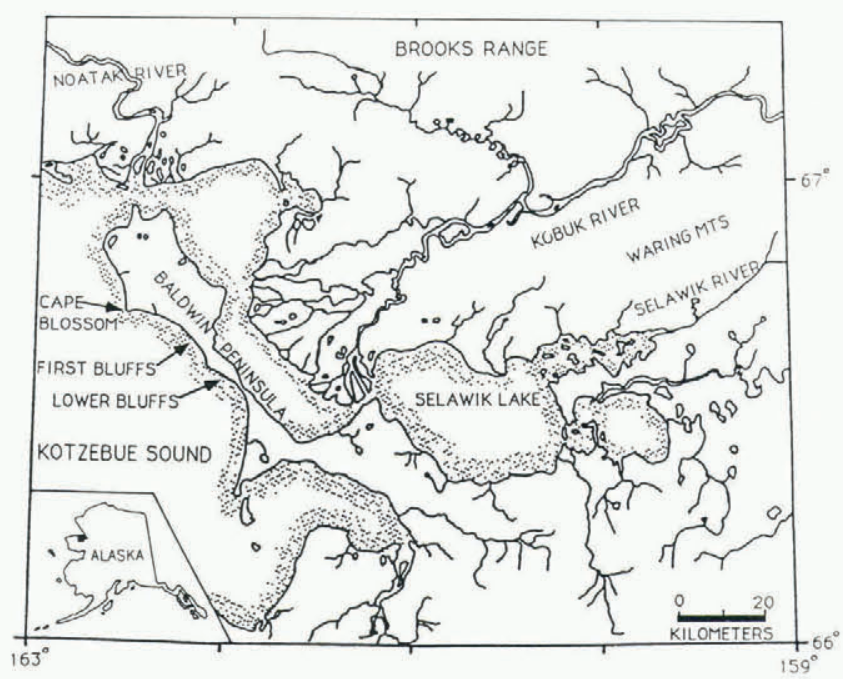

Fig. 1. Location map showing southwest Brooks Range, the Noatak, Kobuk, and Selawik rivers (major drainages for middle Pleistocene glaciers into eastern Kotzebue Sound), and Baldwin Peninsula, a large push-moraine complex.

order of magnitude more areally extensive than deposits of late Pleistocene glaciations in the same region (Hamilton and others, 1986). Similar relationships between early/middle Pleistocene and late Pleistocene ice limits can be found in the central and eastern Brooks Range (Hamilton, 1986), the Seward Peninsula (Kaufman and Hopkins, 1986), and the Chukchi Peninsula in the U..S.S.R. (Arkhipov and others, 1986).

This paper will focus on field evidence, in the form of glaciomarine sediment, for extensive glacierization of the southwest Brooks Range at a time of high relative sea level. We propose various models that explain this conjunction of high sea level and massive glaciation.

\section{SEDIMENTOLOGY AND STRATIGRAPHY}

The sedimentary stratigraphy of Baldwin Peninsula is best observed along beach cliffs of its southwest coast, in particular at Cape Blossom, and in the vicinity of First Bluffs and Lower Bluffs (informal geographic names), southeast of Cape Blossom (Fig. 1).

At First Bluffs and Lower Bluffs, at least three stratified units that pre-date glacial deformation are well exposed. They are, in ascending order, the Cape Blossom Formation, and the Baldwin Silt Member and Selawik 


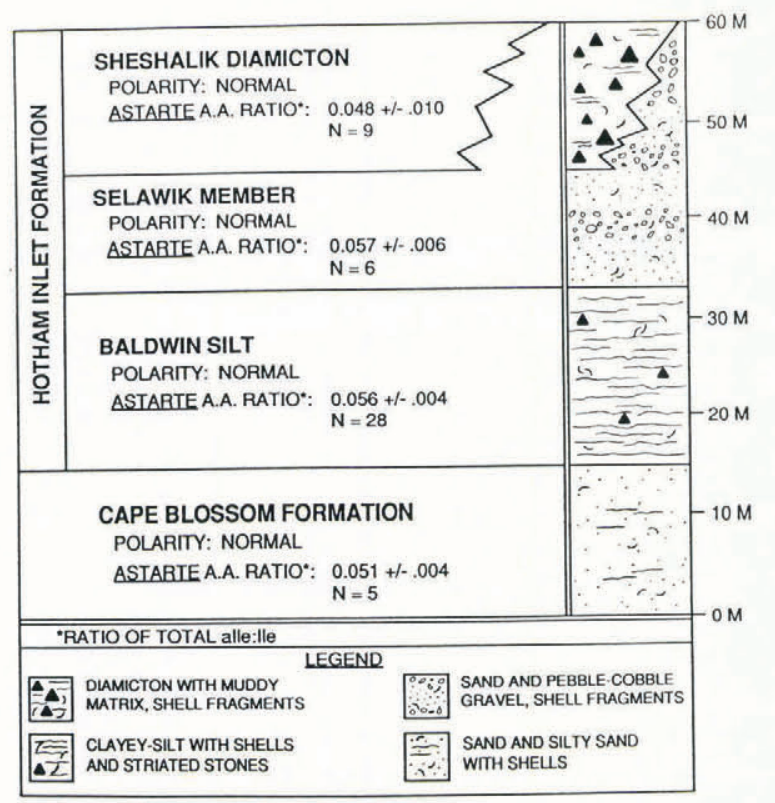

Fig. 2. Litho-, amino-, and magneto-stratigraphy for middle Pleistocene deposits on Baldwin Peninsula.

Member of the Hotham Inlet Formation (Fig. 2). The Baldwin Silt, interpreted as glaciomarine, will be described in detail here. More complete descriptions of the other units may be found elsewhere (Huston and others, 1989).

The Cape Blossom Formation is a planar-to-ripplelaminated medium-to-fine micaceous sand and silty sand, containing marine bivalve and gastropod macrofossils. Its contact with the overlying Baldwin Silt is unconformable and is marked by small sand- and pebble-filled channels and molluscan fossil lags.

The Baldwin Silt of the Hotham Inlet Formation, up to $18 \mathrm{~m}$ thick, is overconsolidated and texturally quite different from the subjacent unit. It is dominantly a massiveto-thinly laminated, dark grey clayey silt and silty clay with almost no sand, and with irregularly spaced, lighter, thin laminae (up to $1 \mathrm{~cm}$ thick, mean $1-2 \mathrm{~mm}$ ) of coarse silt and very fine sand. Striated and faceted exotic stones up to $7 \mathrm{~cm}$ in diameter are found individually and in rare, poorly-sorted lenses up to $25 \mathrm{~cm}$ thick consisting of a mix of silt, sand, and subangular to subrounded pebbles. One of these lenses was found at the unit's basal contact. During field sampling, these erratic stones were quite rare and were not found in all sections. Marine molluscs are common in this unit as fragments, valves, and occasionally paired valves in growth position. Bioturbation in the form of burrows was evident in only a few places. Near its contact with the overlying Selawik Member, the Baldwin Silt commonly coarsens to sandy silt in single thick beds up to $0.5 \mathrm{~m}$, or in intercalated $<0.5 \mathrm{~m}$ beds of clayey silt and sandy silt.

The Baldwin Silt/Selawik Member contact is quite variable. Some sections show unconformities marked by abrupt textural changes and small scours filled with small pebbles, wood fragments and rounded balls of silty clay. Other contacts are quasi-conformable, discernible only by a gradational but unmistakable change from fine silt and clay dominated textures to coarse sand and pebble textures. In two sections, small dewatering structures about $20 \mathrm{~cm}$ high cut through the contact.

The Selawik Member is a loosely consolidated unit of generally coarse textured sediment. It contains numerous intercalated beds of planar- and ripple-laminated, mediumto-fine sand, wavy laminated silty sand, and horizontally stratified pebble-cobble gravel. The Selawik generally coarsens upward and worn wood and shell fragments are found throughout the unit. In places they are cut by penecontemporaneous ice-wedge pseudomorphs.

Extensive, complex exposures of tectonized diamicton (Sheshalik Diamicton of the Hotham Inlet Formation; Fig. 2) and stratified deposits occur at Cape Blossom, about $20 \mathrm{~km}$ northwest of First Bluffs. The glacial stratigraphy of these sections is unclear; however, entrained blocks and slabs, some quite large, of Cape Blossom Formation indicate that the deformed diamictons post-date this marine unit. Matrix texture of the diamicts is in places nearly identical to that of the marine units; they are also fossiliferous, containing abundant shell fragments and occasional unbroken, paired valves of Astarte. The diamicts are rich in striated clasts up to boulder size. Some of the clasts are norite, a mafic plutonic rock found only in the Noatak River drainage. Our interpretation of the Sheshalik Diamicton is not yet complete; it may be ice-proximal glaciomarine, subglacial, or of mixed origins.

Within the complexity of deposits at Cape Blossom are relatively undisturbed sections of stratified sediment similar to, but coarser than, the Baldwin Silt. One particular $10 \mathrm{~m}$ thick section is comprised mostly of massive to laminated dark grey silt and clayey silt with numerous thin stringers of lighter coarse silt and very fine sand, intercalated with light, laminated beds of very fine sandy silt. The dark silt and clayey silt beds contain $<1$ to $5 \%$ small striated pebbles and granules. These sections also contain a few beds, $10-20 \mathrm{~cm}$ thick, of unsorted, matrix supported diamicton containing up to $30 \%$ stones, some striated, with a coarse silt matrix. All of these beds contain shells and shell fragments.

\section{PALEOENVIRONMENTAL INTERPRETATION}

The Cape Blossom Formation is interpreted to record deposition in an interglacial, estuarine environment, not unlike present day eastern Kotzebue Sound. Sediment sources were probably the ancient Noatak, Kobuk, and Selawik rivers (Fig. 3a).

The Baldwin Silt Member is exposed throughout the First Bluffs and Lower Bluffs area. We interpret this unit to be glaciomarine sediment deposited in front of one or more tidewater glaciers that entered Kotzebue Sound from the Noatak, Kobuk, and/or Selawik river valleys during the Anaktuvuk River glaciation (Fig. 3b). The dominant dark grey silty clay and clayey silt texture represents suspension settling from turbid meltwater overflows. The ubiquitous but irregularly-spaced, lighter, thin laminae of coarse silt and very fine sand probably consist mostly of the initial settling products of meltwater overflow plumes, but possibly may consist of aeolian material redeposited during break-up from the winter sea-ice surface (Powell, 1988). Coarse concentrations of striated stones are probably dumps from rolling bergs, while individual stones are from slow berg meltout. Interestingly, a few paired valves of Astarte have been found surrounded by clayey silt but are filled with pure sand. These may have been plucked from the underlying sandy Cape Blossom Formation and then redeposited by icebergs. The paired, unabraided condition of these shells suggests that they were probably enclosed in frozen sediment at the time they were incorporated into glacier ice.

The Baldwin Silt is not exposed over the $20 \mathrm{~km}$ that separate First Bluffs and Cape Blossom; however we believe that the similar but coarser, dropstone-rich stratified silt described at Cape Blossom is correlative with the Baldwin Silt. Its coarseness indicates that it is a more ice-proximal facies than the Baldwin Silt at First Bluffs and Lower Bluffs. If this correlation is correct, fining to the southeast, away from Cape Blossom, suggests that during deposition of the Baldwin Silt, the Noatak River was the dominant source of glaciomarine sediment in eastern Kotzebue Sound (see Fig. 1).

The transition from Baldwin Silt to Selawik Member records a change from a glaciomarine to a subaerial glaciofluvial environment (Fig. 3c). The conformable-tounconformable contact between these two units illustrates that erosional and depositional processes were not acting uniformly across the landscape. Conformable transitions show that in places shoreline regression must have occurred with no downcutting, but with continuous deposition as rapidly aggrading outwash streams filled in the quickly shallowing sound. Dewatering structures rising from the Baldwin Silt were probably induced by loading from rapidly accumulating Selawik Member sand and gravel.

Unconformable contacts probably record erosion in environments where streams were responding more to a descending base level than to increasing loads of outwash 

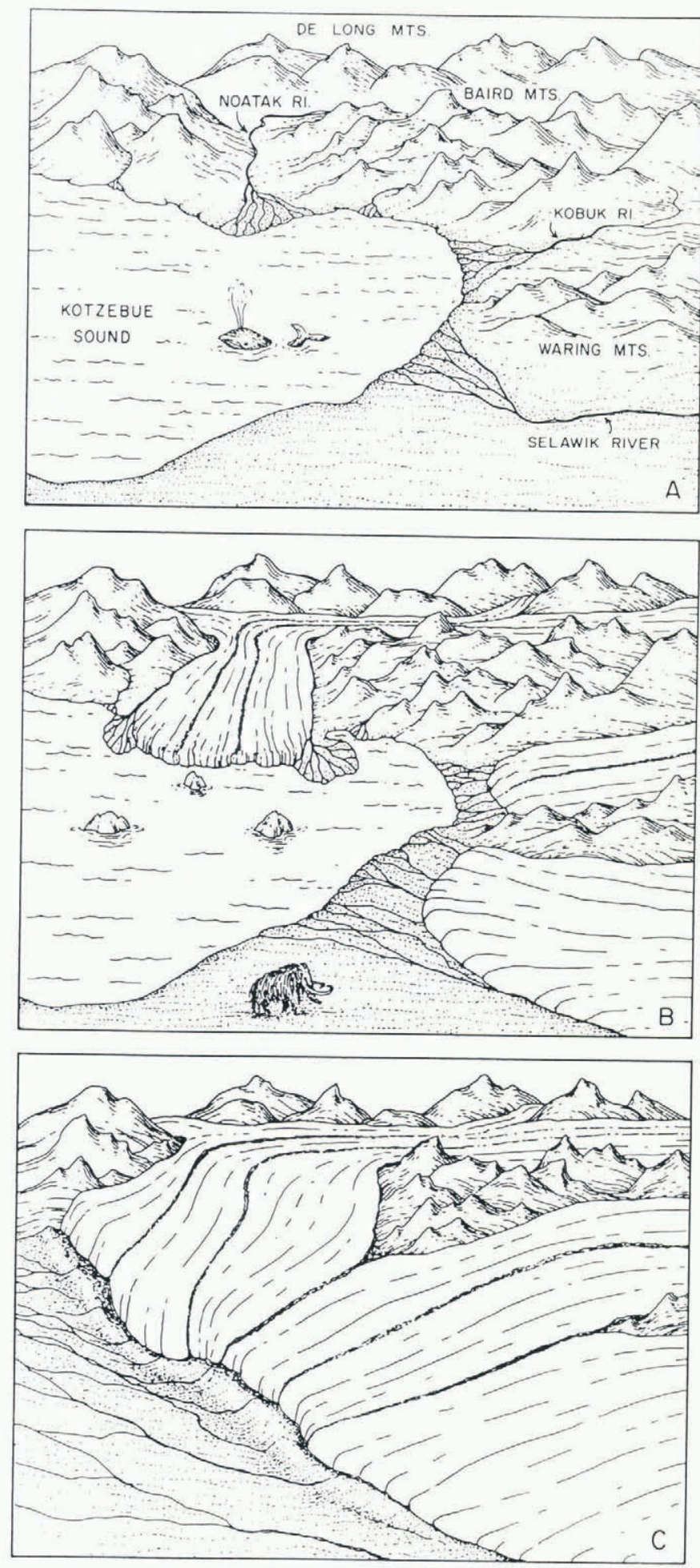

Fig. 3. Paleoenvironmental reconstructions before and during the Anaktuvuk River glaciation. Views are looking to the north. (a) Kotzebue Sound and the southwest Brooks Range (De Long and Baird mts.) prior to glaciation and construction of Baldwin Peninsula. Cape Blossom Formation is being deposited by the Noatak, Kobuk and Selawik rivers. (b) The region during deposition of the Baldwin Silt, with glaciomarine mud being deposited in Kotzebue Sound. Glaciation has not reached its peak and sea level has not been significantly glacio-eustatically lowered. (c) Glaciation has peaked, the Chukchi Sea has retreated, Kotzebue Sound is covered by outwash of the Selawik Member, and Baldwin Peninsula is being constructed as a push moraine.

sediment. Above both types of contact, however, all Selawik Member sections tend to coarsen upward and contain beds of pebble and cobble gravel deposited by outwash streams. Ice wedge pseudomorphs preserved within the Selawik are a testimony to the cold, permafrost climate that accompanied the Anaktuvuk River glaciation.

\section{AGE OF THE KOTZEBUE SOUND GLACIAL DEPOSITS}

Because we have used multiple dating methods, a full discussion of results and methods would be involved but not relevant to the theme of this volume. Geochronology is therefore given as a summary and will be dealt with more fully in future publications by these authors.

Age dating of Anaktuvuk River glaciation deposits at Baldwin Peninsula has been fairly successful. At present, a variety of direct and indirect geochronologic methods have been employed: amino acid analyses of molluscan shells from the Cape Blossom and Hotham Inlet formations (Fig. 2), amino-stratigraphic correlation with marine deposits in northern Alaska (Brigham, 1985), magnetostratigraphy of water-lain, fine-grained sediments in both formations (Fig. 2; M.M. Huston, University of Massachusetts, unpublished data), and morphostratigraphic correlation with $\mathrm{K} / \mathrm{Ar}$ dated Nome River drift on the Seward Peninsula (Kaufman and Hopkins, 1986; D. Turner, University of Alaska, written communication, December 1987). The results from these methods, taken together, indicate that the Anaktuvuk River glaciation probably took place about 500 to $600 \mathrm{ka}$ B.P.

\section{PALEOENVIRONMENTAL SIGNIFICANCE}

The conjunction of anomalously large ice masses in northwest Alaska with a high relative sea level presents two problems. First, why did sea level remain high almost to the peak of the Anaktuvuk River glaciation? Second, why were these middle Pleistocene glaciers so much more extensive than their late Pleistocene Brooks Range counterparts?

During the late Pleistocene, Brooks Range glaciers were much reduced, reaching positions that were nearly $200 \mathrm{~km}$ upvalley from Kotzebue Sound and Baldwin Peninsula (Hamilton and others, 1986). In light of this, and considering the position of Kotzebue Sound near the middle of the continental crust of the broad Bering and Chukchi shelves, it is surprising to find glaciomarine sediments on Baldwin Peninsula. At least three scenarios can explain this:

(1) Advancing ice from the Noatak, Kobuk, and Selawik river valleys may have isostatically depressed the Kotzebue Basin, creating an embayment to the deeper Chukchi Sea. (2) Rather than glaciomarine, the Baldwin Silt sediments may actually be glaciolacustrine, deposited in a large, glacio-isostatically ponded pro-glacial lake.

(3) The Anaktuvuk River glaciation may have preceded the build-up of ice in lower latitudes.

Certainly the large encroaching glaciers of the Anaktuvuk River glaciation must have exerted significant glacio-isostatic effects upon the Kotzebue Sound area, but given the fact that the glaciomarine deposits of the Hotham Inlet Formation lie on continental crust more than $700 \mathrm{~km}$ inside the continental shelf edge of the shallow Chukchi and Bering seas, local isostatic effects could hardly suffice to bring marine waters to Kotzebue Sound at the peak of a global glaciation. Also, given lag times of crustal response to ice loading, if such a depression were to have formed, it would most likely have formed after the sea had glacio-eustatically retreated to a point that would have made flooding of this embayment impossible.

The possibility that the Baldwin Silt is glaciolacustrine is precluded by fossil evidence. Though some enclosed fossils are probably reworked, the presence of numerous marine molluscs in growth position seems to refute this hypothesis. Furthermore, ostracodes enclosed in these sediments are also entirely marine in origin (written communication from E. Browers, U.S.G.S., July 1989).

As an alternative to these glacio-isostatically driven mechanisms, we propose that high latitude glaciation in Beringia preceded glaciation in lower latitudes, thus allowing Anaktuvuk River age glaciers to reach tidewater before significant glacio-eustatic sea-level lowering had occurred.

This proposition leads to the second question of why these glaciers were so extensive relative to later ice bodies. One possibility is that submergence of the Bering and Chukchi shelves could have provided the moisture source 
necessary to grow such large ice masses. Hopkins (1973) made a similar proposal that middle Pleistocene tectonic subsidence and submergence of the Gulf of Anadyr, northwestern Bering Shelf, contributed to the growth of extensive glaciers in northeastern Siberia and northwestern Alaska. While this may also have been the case, glaciomarine evidence in Kotzebue Sound, a relatively stable basin, suggests that the Bering and Chukchi shelves were both submerged over most of their great expanse as glacier ice accumulated.

Secondary (or primary?) to submergence of the shelves, may have been oceanographic and atmospheric circulation patterns that allowed far northward penetration of moisture bearing North Pacific and southern Bering Sea storm systems. At present, winter storms from these sources do not penetrate far over the sea-ice covered northern Bering Sea. Perhaps during early Anaktuvuk River time, such storms had sufficient intensity to extend north past the Bering Strait. Or, on the other hand, the strong winter Arctic High was somehow weakened and no longer provided a buttress against southern storms. Some attenuation of the Arctic high could occur with a reduction in the extent or thickness of the winter Arctic Ocean ice cover.

A mechanism for intensifying northward transport of North Pacific storm systems may be found in an enhanced north-south thermal gradient. This could develop at the close of world-wide interglaciation in response to the conjunction of decreasing insolation at the poles and still relatively warm oceans. Miller (1985) proposed a similar model to explain his observation that major glaciations in the eastern Canadian Arctic were out of phase with global glaciations, occurring at the end of global interglacials.

In summary, it appears certain that the Anaktuvuk River glaciation reached its peak in northwest Alaska at a time when summer radiation had abruptly decreased, but global sea level remained high, thus well before a largescale middle Pleistocene glaciation had reached its peak at lower latitudes. If continuing work confirms tight correlation between the Anaktuvuk River and the Nome River glaciations and a middle Pleistocene glaciation over the Chukchi Peninsula of northeastern Siberia, then this outof-phase middle Pleistocene glacial event will have been shown to have been Beringia-wide.

\section{CONCLUSIONS}

In the southwestern Brooks Range, the Anaktuvuk River glaciation occurred about 500 or $600 \mathrm{ka}$ B.P. Its glaciers were nearly ten times more extensive (Hamilton and others, 1986) than late Wisconsinan age glaciers in the same region. Glaciomarine sediments in the Hotham Inlet Formation indicate that Brooks Range glaciers were able to reach Kotzebue Sound prior to glacio-eustatic sea-level depression. We propose, as did Hopkins (1973), that during this glacial cycle, glaciation in Beringia preceded the build-up of ice elsewhere in the Northern Hemisphere. Indeed, due to moisture source and ice accumulation considerations, it is unlikely that these glaciers could have attained such sizes if the shallow Bering and Chukchi shelves were emergent. This scenario allows the coexistence of massive northwest Alaska glaciers and near modern relative sea level. Large middle Pleistocene ice masses may have also built up in the Brooks Range in response to North Pacific/Bering Sea winter storm systems that penetrated farther northward than the present because they were more intense or the winter Arctic High was attenuated, perhaps by reduced extent or thickness of Arctic Ocean ice cover.

\section{ACKNOWLEDGEMENTS}

This project was supported by National Science
Foundation grants DPP-87-14671 to Brigham-Grette and DPP-87-200025 to Hopkins, and Grants-in-Aid of Research to Huston from the Geological Society of America, Sigma Xi Scientific Society, and the Department of Geology and Geography of the University of Massachusetts. E. Browers, U.S.G.S., kindly examined our microfossil samples. We benefited from discussions with D. Turner, University of Alaska, concerning the reliability of certain $\mathrm{K} / \mathrm{Ar}$ dates, and with P. Bartlein, University of Oregon, concerning the implications of out-of-phase glaciation in Beringia. Thanks to the referees for helpful reviews of the manuscript. Thanks also to D.S. Kaufman (University of Colorado) for valuable discussions and criticism of an earlier draft. We thank W. Trautman for assistance in the field, the National Park Service for their logistical support, and the people and community of Kotzebue for their hospitality and assistance. We thank Marie Litterer for drafting Figure 3.

\section{REFERENCES}

Arkhipov, S.A., L.L. Isayeva, V.G. Bespaly, and O. Glushkova. 1986. Glaciations of Siberia and northeast U.S.S.R. Quat. Sci. Rev., 5, 463-474.

Brigham, J.K. 1985. Marine stratigraphy and amino acid geochronology of the Gubik Formation, western Arctic coastal plain, Alaska. U.S. Geol. Surv. Open-File Rep. 85-381.

Coulter, H.W., D.M. Hopkins, T.N.V. Karlstrom, T.L. Pewe, C. Wahrhaftig, and J.R. Williams. 1965. Map showing the extent of glaciations in Alaska. Scale $1: 2,500,000$. U.S. Geol. Surv. Misc. Maps 1-415.

Hamilton, T.D. 1986. Late Cenozoic glaciation of the central Brooks Range. In Hamilton, T.D., K.M. Reed, and T.M. Thorson, eds. Glaciation in Alaska. The geologic record. Anchorage, AK, Alaska Geological Society, 9-49.

Hamilton, T.D., K.M. Reed, and R.M. Thorson. 1986. Glaciation in Alaska: introduction and overview. In Hamilton, T.D., K.M. Reed, and R.M. Thorson, eds. Glaciation in Alaska. The geologic record. Anchorage, AK, Alaska Geological Society, 1-9.

Hershey, O.H. 1909. The ancient Kobuk Glacier of Alaska. J. Geol., 17(1), 83-91.

Hopkins, D.M. 1967. Quaternary marine transgressions in Alaska. In Hopkins, D.M., ed. The Bering land bridge. Stanford, CA, Stanford University Press, 121-143.

Hopkins, D.M. 1973. Sea level history in Beringia during the past 250,000 years. Quat. Res., 3(4), 520-540.

Huston, M.M., J. Brigham-Grette, and D.M. Hopkins. 1989. Mid-Pleistocene marine and glacial stratigraphy and glaciotectonics, Baldwin Peninsula, northwest Alaska. Lethbridge, Alberta, Abstracts of the 18th Annual Arctic Workshop, 28-30.

Kaufman, D.S. and D.M. Hopkins. 1986. Glacial history of the Seward Peninsula. In Hamilton, T.D., K.M. Reed, and R.M. Thorson, eds. Glaciation in Alaska. The geologic record. Anchorage, AK, Alaska Geological Society, 51-77.

McCulloch, D.S., D.W. Taylor, and M. Rubin. 1965. Stratigraphy, nonmarine mollusks, and radiometric dates from Quaternary deposits in the Kotzebue Sound area, western Alaska. J. Geol., 73(3), 442-453.

Miller, G.H. 1985. Aminostratigraphy of Baffin Island shell-bearing deposits. In Andrews, J.T., ed. Quaternary environments, eastern Canadian Arctic, Baffin Bay and western Greenland. Boston, MA, etc., Allen and Unwin, 394-427.

Powell, R.D. 1988. Processes and facies of temperate and sub-polar glaciers with tidewater fronts. Denver, $\mathrm{CO}$, Geological Society of America. (Short Course Notes.) 